Institute of $\mathbf{F}_{\text {ood and }} \mathbf{A}_{\text {gricultural }} \mathbf{S}_{\text {ciences }}$

\title{
Citrus Reset Analysis ${ }^{1}$
}

\author{
Ronald P. Muraro and Fritz M. Roka ${ }^{2}$
}

\section{Introduction}

Average annual tree loss across the Florida citrus industry ranges between three and four percent. Typical reasons for citrus tree loss include blight, root rot, tristeza, and lightning strikes; however, the extent of tree loss can vary markedly among individual groves. For example, many citrus growers with sour orange rootstocks are losing trees to citrus tristeza virus (CTV) at rates exceeding 25 percent per year. If nothing were done, an entire block of trees on sour orange rootstock would become unprofitable within five years. Economic research by the Florida Department of Citrus (Brown, 1999) has estimated that over 14 percent of orange trees and over 26 percent of seedless grapefruit trees are planted on sour orange rootstock. Thus, if tree loss due to CTV were to exceed 25 percent per year, total annual production could be severely impacted.

Excessive tree losses can have substantial impacts on grove revenues and equity depending on the extent of loss. The costs of tree removal, resetting, and any extra expenses associated with a mixed-age grove add approximately 10 percent to the annual expenditures for a bearing grove (Muraro et al., 2001). Therefore, it is important to evaluate the suitability of regular resetting versus replanting after grove productivity declines to some unprofitable level. For example, if resetting, what should be the frequency, or if replanting, when is the appropriate time? Answers to these questions could be the basis for resetting and replanting strategies.

A citrus grove is a highly capitalized, long-term investment. Evaluating the economic feasibility of tree replacement is an integral part of management decisions. Whether to reset trees when lost due to disease or wait to replant an entire block is dependent upon both horticultural and economic factors. A grove owner could be motivated to replant an entire block if there is a need to change existing infrastructure. For instance, should beds be reshaped for better drainage and/or irrigation? Is the tree density adequate? Is the rootstock/scion combination meeting expected production goals? In addition, changes to marketing programs may dictate that a block be replanted rather than continuing with a reset program. Providing that the grove infrastructure and varietal selections are to be continued, resetting has been shown to be economically beneficial by maintaining a given level of production in a citrus

1. This is EDIS document FE365, a publication of the Department of Food and Resource Economics, Florida Cooperative Extension Service, Institute of Food and Agricultural Sciences, University of Florida, Gainesville, FL. Published March 2003. Please visit the EDIS website at http://edis.ifas.ufl.edu.

2. Ronald P. Muraro, Professor and Extension Economist, Department of Food and Resource Economics, Citrus Research and Education Center, Lake Alfred, FL; and Fritz M. Roka, Associate Professor and Extension Economist, Department of Food and Resource Economics, Southwest Florida Research and Education Center, Immokalee, FL; Florida Cooperative Extension Service, Institute of Food and Agricultural Sciences, University of Florida, Gainesville, FL.

The Institute of Food and Agricultural Sciences is an equal opportunity/affirmative action employer authorized to provide research, educational information and other services only to individuals and institutions that function without regard to race, color, sex, age, handicap, or national origin. For information on obtaining other extension publications, contact your county Cooperative Extension Service office. Florida Cooperative Extension Service/Institute of Food and Agricultural Sciences/University of Florida/Christine Taylor Waddill, Dean. 
grove. However, for replacement trees in a citrus grove to be productive and profitable, a well managed reset program must be maintained. The cash budget analysis discussed in this paper can serve as a "decision-aid" tool for growers to evaluate the economic benefits of resetting or replanting a specific citrus grove.

Citrus growers frequently consider what the optimal tree replacement strategy should be for their individual grove conditions. Should a grower maintain a continuous and immediate reset strategy, or should trees be reset every second or third year? More importantly, at what point in a grove's life should the entire block be replanted as a solid set? If choosing the latter option, a producer should then consider when the block should be replanted. Should it be replanted immediately or delayed to some specified future time? There are horticultural and economic factors, such as tree density, rootstock selection, poor soil drainage, and low market prices, that contribute to low or unsatisfactory production and economic returns. The grove manager should make an evaluation of the grove site, soil type, and rootstock-scion combination, along with the market outlook for the citrus variety in question, before beginning an aggressive resetting/replanting program. Thus, at what point should a grower consider renovating the grove, or changing the rootstock-scion combination, tree density, or bed structure?

A generic answer to these questions is impossible because the tree replacement decision depends upon a number of factors unique to each grove situation. Growers need tools that would allow them to assess the economic returns of alternative tree replacement strategies for their unique set of grove conditions.

\section{The Citrus Reset Analysis Program}

The objective of this project was to develop a tool a citrus grower can use to predict the economic outcomes of various resetting or replanting scenarios. Reset options for replacing trees lost in a citrus grove were discussed in previous Florida State Horticultural Society papers (Muraro and Castle, 1996; Muraro, Roka, and Stansly, 1999). A discounted cash budget model was developed to compare several tree replacement scenarios. A computer budget model was designed as an EXCEL spreadsheet to allow the grower/user to enter actual descriptive data of the grove/block being evaluated for resetting or replanting. Actual grove care costs, price, yield, and expected reset loss rates can be entered by the user. Using the computer model allows several "what if" scenarios to be compared quickly. Six reset or replanting scenarios can be analyzed and compared by the user:

1. reset annually.

2. reset every two years.

3. reset every three years.

4. push and replant an entire grove/block.

5. rapid decline and tree loss (CTV) with removing and replacing trees annually.

6. rapid tree loss (CTV) with no tree replacement and replanting when net return becomes negative.

Example summary tables of the cash budget analysis and annual fruit yields for the six tree replacement scenarios are shown in Tables 1 and 2 (Tables 6 and 10 in the EXCEL Reset Program). To review the Citrus Reset Analysis program, go to the Citrus Research and Education Center (CREC) Cooperative Extension website at http://www.lal.ufl.edu/Extension/ citrusresetanalysis.htm.

The user of the EXCEL Reset Program should check the CREC website to be assured the latest version has been accessed (the words "New Date" will be listed on the INTRODUCTION Worksheet).

Before using the Reset Analysis, it is suggested that you print an example copy first. After accessing the Reset Analysis EXCEL program, you can either print each worksheet separately, or you can print the entire workbook at one time. The process of printing the entire workbook involves four steps: (1) select "File"; (2) select "Print"; (3) select "Entire Workbook"; (4) select "OK". 
To save a working copy of the Citrus Reset Analysis program, right click on "RESET

ANALYSIS" and then left click on "Save target as ..." to save to your disk. The worksheet cells with an orange background indicate where data can be changed.

\section{References}

Brown, M.G., and T.H. Spreen. 2000. An economic assessment of the impact of the citrus tristeza virus on the Florida grapefruit industry. Proceedings of the Florida State Horticulture Society 113: 79-82.

Muraro, R.P., and W.S. Castle. 1996. Resetting and replanting options in Florida citrus groves and the financial consequences. Proceedings of the Florida State Horticulture Society 109: 128-131.

Muraro, R.P., F.M. Roka, and R.E. Rouse. 2002. Budgeting costs and returns for southwest Florida citrus production, 2001-02. Economic Information Report EI-02-10. Department of Food and Resource Economics, University of Florida, Gainesville, FL.

Muraro, R.P., F.M. Roka, and P.A. Stansly. 1999. Reset versus replant: The case of high annual tree loss. Proceedings of the Florida State

Horticulture Society 112: 43-46. 
Table 1. Summary of 15-year cumulative cash flow for reset analysis (Table 6, EXCEL Reset Program).

\begin{tabular}{|c|c|c|}
\hline Existing Variety: Hamlin Oranges & $\begin{array}{l}\text { 15-Year Cash Flow } \\
\text { Nominal/Actual }\end{array}$ & $\begin{array}{l}\text { 15-Year Cash Flow } \\
\text { NPV@10.0\%* }\end{array}$ \\
\hline & $\$ /$ Acre & $\$ /$ Acre \\
\hline Annual Resetting & 6,422 & 2,660 \\
\hline 2-Year Reset Frequency & 6,195 & 2,611 \\
\hline 3-Year Reset Frequency & 5,815 & 2,508 \\
\hline CTV Decline and Resetting CTV Trees Annually & 316 & $(830)$ \\
\hline $\begin{array}{l}\text { CTV Decline and No Resetting and Replant When } \\
\text { Annual Net Return Is Negative }\end{array}$ & 2,811 & $(543)$ \\
\hline $\begin{array}{l}\text { Solid-Set Replanted Block } \\
\text { (Variety: Hamelin Oranges) }\end{array}$ & 5,825 & (30) \\
\hline \multirow[t]{4}{*}{ Annual Tree Loss Rate } & Years & Percentage \\
\hline & Years 1-5 & $2.0 \%$ \\
\hline & Years 6-10 & $1.0 \%$ \\
\hline & Years 11-15 & $3.5 \%$ \\
\hline \multirow[t]{7}{*}{ Expected Annual CTV Tree Loss Rate } & Year & Percentage \\
\hline & Year 1 & $5.0 \%$ \\
\hline & Year 2 & $10.0 \%$ \\
\hline & Year 3 & $15.0 \%$ \\
\hline & Year 4 & $20.0 \%$ \\
\hline & Year 5 & $25.0 \%$ \\
\hline & Year 6 & $25.0 \%$ \\
\hline
\end{tabular}


Table 2. Summary of annual yields per acre for reset analysis (Table 10, EXCEL Reset Program).

\begin{tabular}{|c|c|c|c|c|c|c|}
\hline \multirow[t]{2}{*}{ Year } & \multicolumn{5}{|c|}{ Existing Variety: Hamlin Oranges } & \multirow{2}{*}{$\begin{array}{c}\text { Solid-Set } \\
\text { Replanted Block } \\
\text { (Hamlin Oranges) }\end{array}$} \\
\hline & $\begin{array}{l}\text { Annual } \\
\text { Resetting }\end{array}$ & $\begin{array}{l}\text { Resetting } \\
\text { Every } \\
2 \text { Years }\end{array}$ & $\begin{array}{l}\text { Resetting } \\
\text { Every } \\
3 \text { Years }\end{array}$ & $\begin{array}{c}\text { Rapid CTV } \\
\text { Decline and } \\
\text { Resetting } \\
\text { CTV Trees } \\
\text { Annually }\end{array}$ & $\begin{array}{l}\text { CTV Decline } \\
\text { and No } \\
\text { Resetting and } \\
\text { Replant When } \\
\text { Annual Net } \\
\text { Return Is } \\
\text { Negative }\end{array}$ & \\
\hline & Boxes/Acre & Boxes/Acre & Boxes/Acre & Boxes/Acre & Boxes/Acre & Boxes/Acre \\
\hline 1 & 245 & 245 & 245 & 241 & 241 & 245 \\
\hline 2 & 255 & 255 & 255 & 236 & 236 & 0 \\
\hline 3 & 267 & 267 & 267 & 217 & 217 & 0 \\
\hline 4 & 275 & 274 & 274 & 180 & 0 & 0 \\
\hline 5 & 287 & 285 & 282 & 128 & 0 & 113 \\
\hline 6 & 313 & 309 & 309 & 76 & 0 & 173 \\
\hline 7 & 311 & 307 & 303 & 99 & 113 & 248 \\
\hline 8 & 310 & 304 & 297 & 134 & 173 & 338 \\
\hline 9 & 311 & 304 & 299 & 176 & 248 & 397 \\
\hline 10 & 311 & 303 & 296 & 215 & 338 & 432 \\
\hline 11 & 313 & 305 & 293 & 255 & 397 & 452 \\
\hline 12 & 316 & 304 & 299 & 291 & 432 & 472 \\
\hline 13 & 319 & 309 & 297 & 320 & 452 & 492 \\
\hline 14 & 323 & 310 & 299 & 345 & 472 & 511 \\
\hline 15 & 328 & 317 & 308 & 368 & 492 & 525 \\
\hline
\end{tabular}

